SRNS-STI-2008-00092

Revision \# 0

\title{
MELT RATE FURNACE TESTING FOR SLUDGE BATCH 5 FRIT OPTIMIZATION
}

D. H. Miller

K. M. Fox

B. R. Pickenheim

M. E. Stone

September 2008

Environmental \& Chemical Process Technology Savannah River National Laboratory

Aiken, SC 29808

Prepared for the U.S. Department of Energy Under Contract Number DEAC09-08SR22470

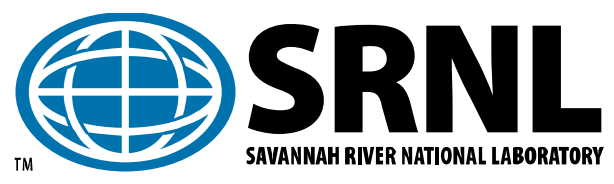




\section{DISCLAIMER}

This work was prepared under an agreement with and funded by the U.S. Government. Neither the U.S. Government or its employees, nor any of its contractors, subcontractors or their employees, makes any express or implied: 1. warranty or assumes any legal liability for the accuracy, completeness, or for the use or results of such use of any information, product, or process disclosed; or 2. representation that such use or results of such use would not infringe privately owned rights; or 3. endorsement or recommendation of any specifically identified commercial product, process, or service. Any views and opinions of authors expressed in this work do not necessarily state or reflect those of the United States Government, or its contractors, or subcontractors.

This document was prepared in conjunction with work accomplished under Contract No. DEAC09-08SR22470 with the U.S. Department of Energy. 
Key Words: $D W P F, S B 5$, Frit, Melt Rate

\author{
Retention: Permanent
}

\title{
MELT RATE FURNACE TESTING FOR SLUDGE BATCH 5 FRIT OPTIMIZATION
}

D. H. Miller

K. M. Fox

B. R. Pickenheim

M. E. Stone

September 2008

Environmental \& Chemical Process Technology Savannah River National Laboratory Aiken, SC 29808

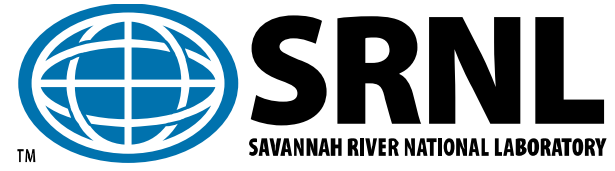




\section{REVIEWS AND APPROVALS}

\section{AUTHORS:}

D. H. Miller, Process Engineering Technology

Date

K. M. Fox, Process Engineering Technology

Date

B. R. Pickenheim, Process Engineering Technology

Date

M. E. Stone, Process Engineering Technology

Date

\section{TECHNICAL REVIEWER:}

D. K. Peeler, Process Engineering Technology

Date

\section{APPROVERS:}

J. C. Griffin, Manager,

Date

Environmental \& Chemical Process Technology Research Programs

C. C. Herman, Manager, Process Engineering Technology

Date

J. E. Occhipinti, Manager,

Date

Waste Solidification Engineering 


\section{EXECUTIVE SUMMARY}

Savannah River National Laboratory (SRNL) was requested to provide the Defense Waste Processing Facility (DWPF) with a frit composition for Sludge Batch 5 (SB5) to optimize processing. A series of experiments were designed for testing in the Melt Rate Furnace (MRF). This dry fed tool can be used to quickly determine relative melt rates for a large number of candidate frit compositions and lead to a selection for further testing. Simulated Sludge Receipt and Adjustment Tank (SRAT) product was made according to the most recent SB5 sludge projections and a series of test were conducted with frits that covered a range of boron and alkali ratios. Several frits with relatively large projected operating windows indicated melt rates that would not severely impact production. As seen with previous MRF testing, increasing the boron concentration had positive impacts on melt rate on the SB5 system. However, there appears to be maximum values for both boron and sodium above which the there is a negative effect on melt rate. Based on these data and compositional trends, Frit 418 and a specially designed frit (Frit 550) have been selected for additional melt rate testing. Frit 418 and Frit 550 will be run in the Slurry Fed Melt Rate Furnace (SMRF), which is capable of distinguishing rheological properties not detected by the MRF. Frit 418 will be used initially for SB5 processing in DWPF (given its robustness to compositional uncertainty). The Frit 418-SB5 system will provide a baseline from which potential melt rate advantages of Frit 550 can be gauged. The data from SMRF testing will be used to determine whether Frit 550 should be recommended for implementation in DWPF. 


\section{TABLE OF CONTENTS}

EXECUTIVE SUMMARY ............................................................................................... IV

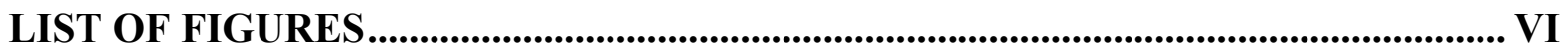

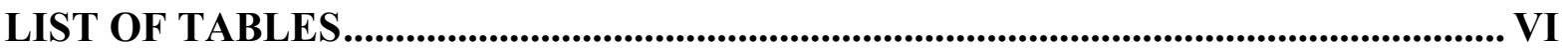

LIST OF ACRONYMS ............................................................................................................VII

1.0 INTRODUCTION ........................................................................................................

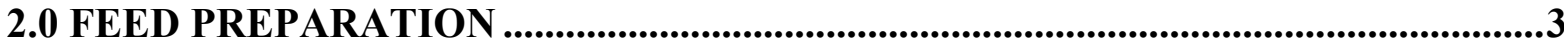

2.1 FeEd Preparations for SB5 Initial Melt Rate Testing...........................................

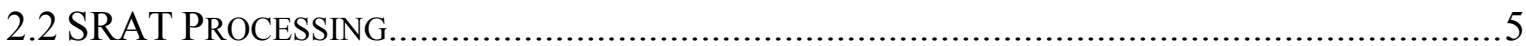

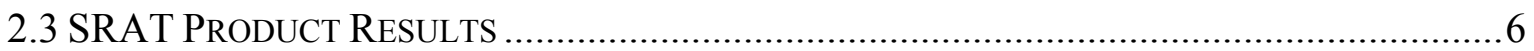

2.4 FeEd Preparation for SB5 Phase 3 Melt Rate Testing .......................................... 7

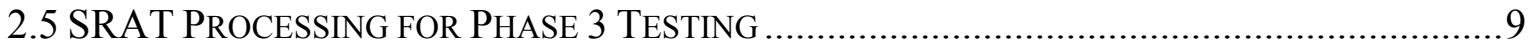

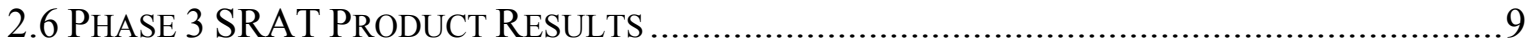

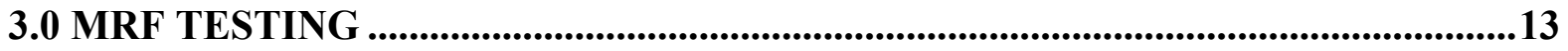

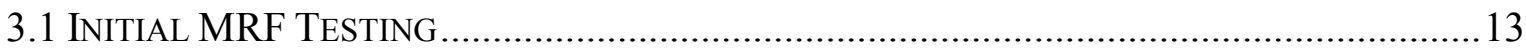

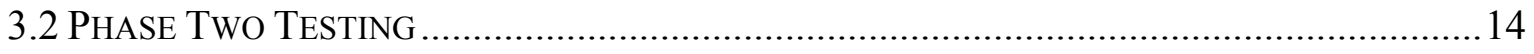

3.3 PhaSe Three TeSTING ....................................................................................... 15

4.0 CONCLUSIONS/RECOMMENDATIONS ..................................................................18

5.0 REFERENCES ...............................................................................................................20

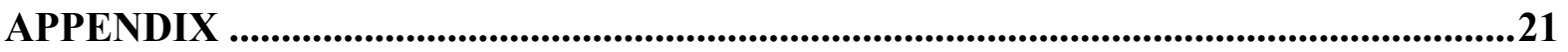




\section{LIST OF FIGURES}

Figure 1. Frit 418 (left) and Frit 503 (right) Sectioned Beakers..........................................15

Figure 2. Frit 540 (left) and Frit 542 (right) Sectioned Beakers........................................ 16

\section{LIST OF TABLES}

Table 1. Projected and Recipe Elemental Compositions....................................................

Table 2. SB5-2 Simulant Elemental Composition Results ............................................... 4

Table 3. SB5-2 Anion Composition and Solids Results.....................................................5

Table 4. Acid Calculation Results .................................................................................... 6

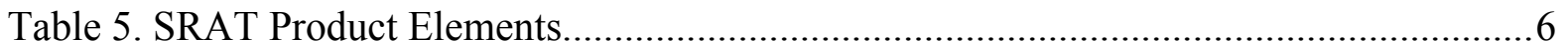

Table 6. SRAT Product Anion Results.......................................................................... 7

Table 7. Projected and Recipe Elemental Compositions................................................... 8

Table 8. Anions and Solids Results .................................................................................. 8

Table 9. Key Acid Calculation Parameters ......................................................................... 9

Table 10. SB5-16 SRAT Product Elements (calcined basis) ............................................... 10

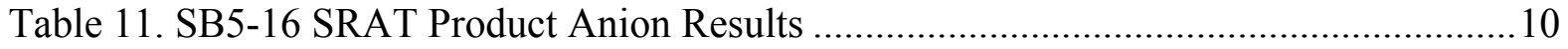

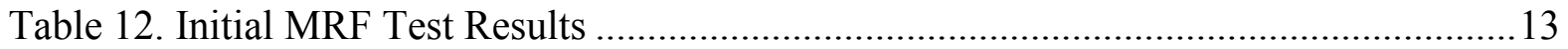

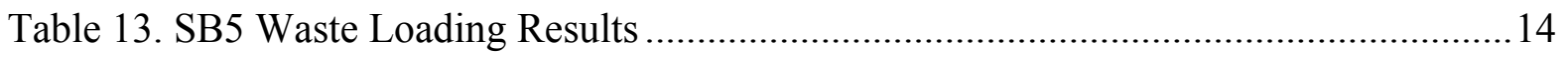

Table 14. Candidate SB5 Frit Compositions (Weight \%) ................................................. 15

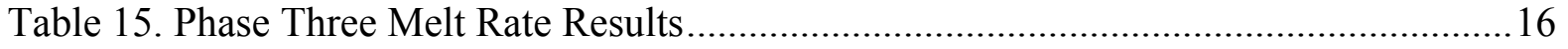




\section{LIST OF ACRONYMS}

$\begin{array}{ll}\text { ACTL } & \text { Aiken County Technologies Laboratory } \\ \text { CPC } & \text { Chemical Process Cell } \\ \text { DOE } & \text { Department of Energy } \\ \text { DWPF } & \text { Defense Waste Processing Facility } \\ \text { MAR } & \text { Measurement Acceptability Region } \\ \text { MRF } & \text { Melt Rate Furnace } \\ \text { PCCS } & \text { Product Composition Control System } \\ \text { REDOX } & \text { REDuction/OXidation } \\ \text { SB3 } & \text { Sludge Batch 3 } \\ \text { SB4 } & \text { Sludge Batch 4 } \\ \text { SB5 } & \text { Sludge Batch 5 } \\ \text { SMR } & \text { Sludge Mass Reduction } \\ \text { SMRF } & \text { Slurry-Fed Melt Rate Furnace } \\ \text { SRAT } & \text { Sludge Receipt and Adjustment Tank } \\ \text { SRNL } & \text { Savannah River National Laboratory } \\ \text { TIC } & \text { Total Inorganic Carbon } \\ \text { TTR } & \text { Technical Task Request } \\ \text { WL } & \text { Waste Loading }\end{array}$




\subsection{INTRODUCTION}

Savannah River National Laboratory (SRNL) was requested to provide the Defense Waste Processing Facility (DWPF) with a frit composition for Sludge Batch 5 (SB5) to optimize processing via Technical Task Request HLW-DWPF-TTR-2007-0007 ${ }^{1}$. A Task Technical \& Quality Assurance Plan was written and approved to meet the objectives of this request ${ }^{2}$. This report discusses the results of a series of tests that have been completed and the preparation of the feed used in the testing. Sludge batch projection changes led to the fabrication and testing of several new frits along with frits that have been utilized previously in the DWPF. Melt rate testing in the dry fed Melt Rate Furnace (MRF) has been completed and frit candidates identified. The rationale for the choice of the SB5 composition and frits for these MRF tests is documented elsewhere ${ }^{3}$.

This document addresses a series of SB5 MRF testing that was conducted in three phases. The initial phase involved testing with 5 frits that covered a range of $\mathrm{B}_{2} \mathrm{O}_{3}$ and alkali values at $38 \%$ waste loading (WL). The second phase was conducted with two frits selected from the first series, but at different waste loadings (to assess the impact of waste loading on melt rate to provide insight into the waste throughput curve) and with replication of individual melts. Based on the results of the first two phases, a third phase was defined to evaluate additional frits containing higher levels of $\mathrm{B}_{2} \mathrm{O}_{3}$ and $\mathrm{Na}_{2} \mathrm{O}$ along with varying $\mathrm{Li}_{2} \mathrm{O}$ contents. A description of the processing to make the SB5 simulants is also included. 
SRNS-STI-2008-00092

Revision 0

This page intentionally left blank. 


\subsection{FEED PREPARATION}

Two batches of SB5 simulant product were made in the Sludge Receipt and Adjustment Tank (SRAT) process at the Aiken County Technologies Laboratory (ACTL). The first 22 liter SRAT batch, designated SB5-6, was prepared using the SB5 Case F projection as the starting sludge. This composition is based on the results of the Al-dissolution demonstration performed in the SRNL Shielded Cells facility ( $\sim 40 \%$ Al removal) ${ }^{3}$ and early projections of the mass and composition of Tank 7 with an assumed heel of Sludge Batch 4. The SB5 Case F projection was used during the first and second phase of testing. The second batch used to support Phase 3 MRF testing is described in Section 2.4.

\subsection{Feed Preparations for SB5 Initial Melt Rate Testing}

Initial simulant was prepared and processed through the DWPF SRAT process to prepare SRAT product for melt rate testing. This material was used to complete MRF testing runs MRF 08-023 through MRF 08-033. The SB5 sludge composition (designated SB5-2) target was developed based on best projections of the SB5 blended feed in February 2008 (SB5 Case F as described above). Compositions of the sludge simulants were renormalized after removal of radioactive species from the elemental compositions and adjusted for charge balance as required. The nonradioactive, renormalized composition is referred to as the "SB5-2 Recipe" projection. Elemental projected composition and recipe targets for the simulant are shown in Table 1.

\section{Table 1 Projected and Recipe Elemental Compositions}

\begin{tabular}{|c|c|c|}
\hline & $\begin{array}{l}\text { SB5(CASE F) } \\
\text { Projection }\end{array}$ & $\begin{array}{l}\text { SB5-2 } \\
\text { Recipe }\end{array}$ \\
\hline & $\begin{array}{l}\text { Oxide } \\
\text { Wt } \%\end{array}$ & $\begin{array}{l}\text { Oxide } \\
\text { Wt \% }\end{array}$ \\
\hline $\mathrm{Al}_{2} \mathrm{O}_{3}$ & 27.17 & 29.48 \\
\hline $\mathrm{BaO}$ & 0.11 & 0.12 \\
\hline $\mathrm{CaO}$ & 1.88 & 2.04 \\
\hline $\mathrm{Ce}_{2} \mathrm{O}_{3}$ & 0.39 & 0.42 \\
\hline $\mathrm{Cr}_{2} \mathrm{O}_{3}$ & 0.39 & 0.42 \\
\hline $\mathrm{CuO}$ & 0.01 & 0.01 \\
\hline $\mathrm{Fe}_{2} \mathrm{O}_{3}$ & 24.48 & 26.56 \\
\hline $\mathrm{K}_{2} \mathrm{O}$ & 0.07 & 0.06 \\
\hline $\mathrm{La}_{2} \mathrm{O}_{3}$ & 0.17 & 0.18 \\
\hline $\mathrm{MgO}$ & 1.24 & 1.34 \\
\hline $\mathrm{MnO}_{2}$ & 6.28 & 6.81 \\
\hline $\mathrm{Na}_{2} \mathrm{O}$ & 24.22 & 26.27 \\
\hline $\mathrm{NiO}$ & 2.86 & 3.11 \\
\hline $\mathrm{PbO}$ & 0.02 & 0.02 \\
\hline $\mathrm{SiO}_{2}$ & 1.97 & 2.14 \\
\hline $\mathrm{ThO}_{2}$ & - & - \\
\hline $\mathrm{TiO}_{2}$ & 0.03 & 0.68 \\
\hline $\mathrm{U}_{3} \mathrm{O}_{8}$ & 7.28 & - \\
\hline $\mathrm{ZnO}$ & 0.02 & 0.02 \\
\hline $\mathrm{ZrO}_{2}$ & 0.27 & 0.28 \\
\hline
\end{tabular}


Elemental compositions were measured after preparation was complete. The compositions matched the targets for all major species, as shown in Table 2. The anion composition and solids results for the simulant are shown in Table 3.

Table 2 SB5-2 Simulant Elemental Composition Results

\begin{tabular}{||c|c|c|c||}
\hline \hline & Recipe & Result & Difference \\
\hline & Oxide & Oxide & \\
\hline & Wt \% & Wt \% & \% \\
\hline $\mathrm{Al}_{2} \mathrm{O}_{3}$ & 29.48 & 29.295 & 0.63 \\
\hline $\mathrm{BaO}$ & 0.12 & 0.117 & 2.47 \\
\hline $\mathrm{CaO}$ & 2.04 & 2.191 & 7.40 \\
\hline $\mathrm{Ce}_{2} \mathrm{O}_{3}$ & 0.42 & 0.424 & 0.89 \\
\hline $\mathrm{Cr}_{2} \mathrm{O}_{3}$ & 0.42 & 0.375 & 10.66 \\
\hline $\mathrm{CuO}$ & 0.01 & 0.028 & 175.00 \\
\hline $\mathrm{Fe}_{2} \mathrm{O}_{3}$ & 26.56 & 28.028 & 5.53 \\
\hline $\mathrm{K}_{2} \mathrm{O}$ & 0.06 & 0.110 & 83.00 \\
\hline $\mathrm{La}_{2} \mathrm{O}_{3}$ & 0.18 & $*$ & $*$ \\
\hline $\mathrm{MgO}$ & 1.34 & 1.247 & 6.97 \\
\hline $\mathrm{MnO}_{2}$ & 6.81 & 6.834 & 0.35 \\
\hline $\mathrm{Na}_{2} \mathrm{O}$ & 26.27 & 24.368 & 7.24 \\
\hline $\mathrm{NiO}_{1}$ & 3.11 & 3.207 & 3.11 \\
\hline $\mathrm{PbO}_{3}$ & 0.02 & 0.000 & 100.0 \\
\hline $\mathrm{SiO}$ & 2.14 & 2.172 & 1.50 \\
\hline $\mathrm{TiO}_{2}$ & 0.68 & 0.029 & 95.7 \\
\hline $\mathrm{ZnO}$ & 0.02 & 0.293 & 1363 \\
\hline $\mathrm{ZrO}$ & 0.28 & 0.144 & 48.65 \\
\hline \hline
\end{tabular}

* Not Measured 
Table 3 SB5-2 Anion Composition and Solids Results

\begin{tabular}{||l|c|c||}
\hline & Simulant & Units \\
\hline $\mathrm{F}$ & $<100$ & $\mathrm{mg} / \mathrm{kg}$ slurry \\
\hline $\mathrm{Cl}$ & 305.5 & $\mathrm{mg} / \mathrm{kg}$ slurry \\
\hline $\mathrm{NO}_{2}$ & 7545 & $\mathrm{mg} / \mathrm{kg}$ slurry \\
\hline $\mathrm{NO}_{3}$ & 5610 & $\mathrm{mg} / \mathrm{kg}$ slurry \\
\hline $\mathrm{SO}_{4}$ & 996 & $\mathrm{mg} / \mathrm{kg}$ slurry \\
\hline $\mathrm{PO}_{4}$ & $<100$ & $\mathrm{mg} / \mathrm{kg}$ slurry \\
\hline $\mathrm{HCO}_{2}$ & 195 & $\mathrm{mg} / \mathrm{kg}$ slurry \\
\hline $\mathrm{C}_{2} \mathrm{O}_{4}$ & $<100$ & $\mathrm{mg} / \mathrm{kg}$ slurry \\
\hline $\mathrm{TIC}$ & 1,484 & $\mathrm{mg} / \mathrm{kg}$ slurry \\
\hline Base Eq. & 1.01 & $\mathrm{molar}$ \\
\hline Total Solids & 17.5 & $\mathrm{wt} \%$ \\
\hline Soluble Solids & 6.3 & $\mathrm{wt} \%$ \\
\hline Insoluble Solids & 11.1 & $\mathrm{wt} \%$ \\
\hline Calcine Solids & 13.5 & $\mathrm{wt} \%$ \\
\hline pH & 13.2 & \\
\hline Density & 1.17 & $\mathrm{~g} / \mathrm{ml}$ \\
\hline \hline
\end{tabular}

\subsection{SRAT Processing}

Two SRAT runs were performed in the 22L SRAT vessels to provide feed for initial melt rate testing using SB5 simulant. The laboratory testing was conducted in accordance with procedure ITS-0094 of the L29 manual: "Laboratory Scale Chemical Process Cell Simulations". The experimental apparatus was set up using the guidance of SRNL-PSE-2006-00074 utilizing a 22L SRAT/SME vessel. The SRAT product (designated SB5-6) was manufactured under SB5-6 Run Plan, SRNL-PSE-2008-00056. At the conclusion of the SRAT cycles, the SRAT products from the duplicate runs were blended and one $125 \mathrm{ml}$ sample was pulled from each of the blended SRAT products.

Mercury is not typically added to feed intended for use in melt rate testing, and no mercury was added during the runs for these tests. Noble metals were also excluded from these runs, a change from past protocols. Higher rates of formic acid destruction have been noted during melt rate testing without mercury as compared to runs with mercury during flowsheet evaluations. These higher destruction rates lead to melter feed with higher yield stress and less formate than comparable flowsheet runs. Given the higher hydrogen generation rates seen as a result of the higher formic acid destruction, adjusting the acid calculation to add more formic acid to account for the differences between the flowsheet runs and melt rate feed preparation runs was deemed less practical than eliminating the noble metals and adjusting the acid calculation for less formic acid destruction. The gas chromatograph analysis of the offgas is not needed for runs without noble metals; therefore the elimination of noble metals also represents a reduction in cost and complexity of the runs.

The standard acid calculations for Chemical Process Cell (CPC) process simulations were completed based on the sample results from each run. The input assumptions, sample results utilized, and calculation results are shown in Appendix A. A summary of key assumptions and results is shown in Table 4. 
Table 4 Acid Calculation Results

\begin{tabular}{|l|c|l||}
\hline \multicolumn{1}{|c|}{ Results of Acid Calculation } & SB5-6 & Units \\
\hline & & \\
\hline Stoichiometric factor & 130 & $\%$ \\
\hline Nitrite to Nitrate Conversion & 25 & $\%$ of nitrite in feed \\
\hline Formic Acid Destruction & 10 & $\%$ of formic acid added \\
\hline Acid Addition Amount & 2.076 & $\mathrm{~g} / \mathrm{mol}$ per liter \\
\hline Ratio of Formic Acid to total Acid & 0.818 & $\mathrm{~mol}$ formic $/ \mathrm{mol}$ acid \\
\hline
\end{tabular}

\subsection{SRAT Product Results}

The elemental compositions for the SB5-6 SRAT product matched the sludge recipe targets, as shown in Table 5. The anion and solids results are shown in Table 6.

Table 5 SRAT Product Elements

\begin{tabular}{||c|c|c||}
\hline & SB5-2 & SB5-6 \\
\hline & Recipe & Measured \\
\hline & Oxide & Oxide \\
\hline & Wt \% & Wt \% \\
\hline $\mathrm{Al}_{2} \mathrm{O}_{3}$ & 29.48 & 29.77 \\
\hline $\mathrm{BaO}$ & 0.12 & 0.11 \\
\hline $\mathrm{CaO}$ & 2.04 & 2.12 \\
\hline $\mathrm{Ce}_{2} \mathrm{O}_{3}$ & 0.42 & 0.41 \\
\hline $\mathrm{Cr}_{2} \mathrm{O}_{3}$ & 0.42 & 0.37 \\
\hline $\mathrm{CuO}$ & 0.01 & 0.03 \\
\hline $\mathrm{Fe}_{2} \mathrm{O}_{3}$ & 26.56 & 26.53 \\
\hline $\mathrm{K}_{2} \mathrm{O}$ & 0.06 & 0.12 \\
\hline $\mathrm{La}_{2} \mathrm{O}_{3}$ & 0.18 & 0.18 \\
\hline $\mathrm{MgO}_{2} \mathrm{1}$ & 1.34 & 1.21 \\
\hline $\mathrm{MnO}_{2}$ & 6.81 & 6.58 \\
\hline $\mathrm{Na}_{2} \mathrm{O}$ & 26.27 & 25.31 \\
\hline $\mathrm{NiO}_{1}$ & 3.11 & 3.12 \\
\hline $\mathrm{PbO}$ & 0.02 & 0.00 \\
\hline $\mathrm{SiO}_{2}$ & 2.14 & 2.31 \\
\hline $\mathrm{ThO}_{2}$ & - & - \\
\hline $\mathrm{TiO}_{2}$ & 0.68 & 0.02 \\
\hline $\mathrm{U}_{3} \mathrm{O}_{8}$ & - & - \\
\hline $\mathrm{ZnO}_{2}$ & 0.02 & 0.02 \\
\hline $\mathrm{ZrO}_{2}$ & 0.28 & 0.14 \\
\hline \hline
\end{tabular}


Table 6 SRAT Product Anion Results

\begin{tabular}{||l|c|c||}
\hline & SB5-6 & Units \\
\hline $\mathrm{F}$ & $<100$ & $\mathrm{mg} / \mathrm{kg}$ slurry \\
\hline $\mathrm{Cl}$ & $<100$ & $\mathrm{mg} / \mathrm{kg}$ slurry \\
\hline $\mathrm{NO}_{2}$ & $<100$ & $\mathrm{mg} / \mathrm{kg}$ slurry \\
\hline $\mathrm{NO}_{3}$ & 29,100 & $\mathrm{mg} / \mathrm{kg}$ slurry \\
\hline $\mathrm{SO}_{4}$ & - & $\mathrm{mg} / \mathrm{kg}$ slurry \\
\hline $\mathrm{PO}_{4}$ & $<100$ & $\mathrm{mg} / \mathrm{kg}$ slurry \\
\hline $\mathrm{HCO}_{2}$ & $<100$ & $\mathrm{mg} / \mathrm{kg}$ slurry \\
\hline $\mathrm{C}_{2} \mathrm{O}_{4}$ & $<100$ & $\mathrm{mg} / \mathrm{kg}$ slurry \\
\hline Total Solids & 25.24 & $\mathrm{wt} \%$ \\
\hline Soluble Solids & 12.67 & $\mathrm{wt} \%$ \\
\hline Insoluble Solids & 12.57 & $\mathrm{wt} \%$ \\
\hline Calcine Solids & 14.91 & $\mathrm{wt} \%$ \\
\hline pH & 4.45 & $\mathrm{~g} / \mathrm{ml}$ \\
\hline Density & 1.23 & \multicolumn{2}{|l||}{} \\
\hline
\end{tabular}

\subsection{Feed Preparation for SB5 Phase 3 Melt Rate Testing}

Phase 3 of MRF testing was conducted with SRAT product made from a new batch of stimulant. This SRAT batch was designated as SB5-16 and was used to complete MRF testing starting with run MRF 08-69 and continuing through run MRF 08-076.

A simulant to match the April 2008 projected Sludge Batch 5 (SB5-C) composition was processed through the DWPF SRAT process to prepare this second batch of feed. The elemental composition targets were developed based on tank farm projections of the SB5 Tank 40 blended feed. The basis for this simulant are discussed in a recently issued report. ${ }^{4}$ Compositions of the sludge simulants were renormalized after removal of radioactive species from the elemental compositions and adjustment for charge balance as required (referred to as the "Recipe" composition or projection). Elemental composition targets and results are shown in Table 7, while anion composition and solids results are shown in Table 8. 
Table 7 Projected and Recipe Elemental Compositions

\begin{tabular}{|c|c|c|c|}
\hline & $\begin{array}{l}\text { SB5(April } \\
\text { 08) } \\
\text { Projection }\end{array}$ & $\begin{array}{l}\text { SB5-C } \\
\text { Recipe }\end{array}$ & $\begin{array}{c}\text { SB5-C } \\
\text { Measured } \\
\text { Result } \\
\end{array}$ \\
\hline & $\begin{array}{l}\text { Oxide } \\
\text { Wt \% }\end{array}$ & $\begin{array}{l}\text { Oxide } \\
\text { Wt \% }\end{array}$ & $\begin{array}{l}\text { Oxide } \\
\text { Wt \% }\end{array}$ \\
\hline $\mathrm{Al}_{2} \mathrm{O}_{3}$ & 22.22 & 23.96 & 23.72 \\
\hline $\mathrm{BaO}$ & 0.02 & 0.02 & 0.02 \\
\hline $\mathrm{CaO}$ & 2.57 & 2.77 & 2.95 \\
\hline $\mathrm{Ce}_{2} \mathrm{O}_{3}$ & 0.01 & 0.01 & 0.03 \\
\hline $\mathrm{Cr}_{2} \mathrm{O}_{3}$ & 0.04 & 0.04 & 0.02 \\
\hline $\mathrm{CuO}$ & 0.01 & 0.01 & 0.02 \\
\hline $\mathrm{Fe}_{2} \mathrm{O}_{3}$ & 30.15 & 32.52 & 30.67 \\
\hline $\mathrm{K}_{2} \mathrm{O}$ & 0.06 & 0.06 & 0.19 \\
\hline $\mathrm{La}_{2} \mathrm{O}_{3}$ & 0.01 & 0.01 & 0.00 \\
\hline $\mathrm{MgO}$ & 1.67 & 1.80 & 1.48 \\
\hline $\mathrm{MnO}_{2}$ & 7.72 & 8.33 & 7.98 \\
\hline $\mathrm{Na}_{2} \mathrm{O}$ & 22.35 & 24.10 & 23.56 \\
\hline $\mathrm{NiO}$ & 3.33 & 3.59 & 3.33 \\
\hline $\mathrm{PbO}$ & 0.01 & 0.01 & 0.00 \\
\hline $\mathrm{SiO}_{2}$ & 2.52 & 2.72 & 2.71 \\
\hline $\mathrm{TiO}_{2}$ & 0.02 & 0.02 & 0.00 \\
\hline $\mathrm{U}_{3} \mathrm{O}_{8}$ & 8.14 & - & - \\
\hline $\mathrm{ZrO}_{2}$ & 0.01 & 0.01 & 0.00 \\
\hline
\end{tabular}

Table 8 Anions and Solids Results

\begin{tabular}{||c|c|c||}
\hline & SB5 -C & Units \\
\hline $\mathrm{F}$ & $<100$ & $\mathrm{mg} / \mathrm{kg}$ slurry \\
\hline $\mathrm{Cl}$ & $<100$ & $\mathrm{mg} / \mathrm{kg}$ slurry \\
\hline $\mathrm{NO}_{2}$ & 6175 & $\mathrm{mg} / \mathrm{kg}$ slurry \\
\hline $\mathrm{NO}_{3}$ & 3940 & $\mathrm{mg} / \mathrm{kg}$ slurry \\
\hline $\mathrm{SO}_{4}$ & 405 & $\mathrm{mg} / \mathrm{kg}$ slurry \\
\hline $\mathrm{PO}_{4}$ & $<100$ & $\mathrm{mg} / \mathrm{kg}$ slurry \\
\hline $\mathrm{HCO}_{2}$ & 63300 & $\mathrm{mg} / \mathrm{kg}$ slurry \\
\hline $\mathrm{TIC}$ & 1338 & $\mathrm{mg} / \mathrm{kg}$ slurry \\
\hline Base Eq. & 0.632 & $\mathrm{molar}$ \\
\hline Total Solids & 12.50 & $\mathrm{wt} \%$ \\
\hline Soluble Solids & 4.65 & $\mathrm{wt} \%$ \\
\hline Insoluble Solids & 7.85 & $\mathrm{wt} \%$ \\
\hline Calcined Solids & 9.51 & $\mathrm{wt} \%$ \\
\hline $\mathrm{pH}$ & 13.4 & \\
\hline Density & 1.09 & $\mathrm{~g} / \mathrm{ml}$ \\
\hline
\end{tabular}




\subsection{SRAT Processing for Phase 3 Testing}

One SRAT run in a 22L SRAT vessel was performed to provide feed for melt rate testing using SB5-C. The laboratory procedure and experimental apparatus set up was the same as that used in the initial testing. The SRAT product (designated SB5-16) was manufactured under SB5-16 Run Plan: SRNL-PSE-2008-00165. Neither mercury nor noble metals were added to the feed per the current protocol for feed prepared for melt rate testing.

The standard acid calculation for CPC process simulations was completed based on SB5-C sample results. The input assumptions, sample results utilized, and calculation results are shown in Appendix B. A summary of key assumptions and results is shown in Table 9.

Table 9 Key Acid Calculation Parameters

\begin{tabular}{||l|c|l||}
\hline \multicolumn{1}{|c|}{ Results of Acid Calculation } & SB5-16 & Units \\
\hline & & \\
\hline Stoichiometric factor & 130 & $\%$ \\
\hline Nitrite to Nitrate Conversion & 25 & $\%$ of nitrite in feed \\
\hline Formic Acid Destruction & 15 & $\%$ of formic acid added \\
\hline Acid Addition Amount & 1.43 & $\mathrm{~g} / \mathrm{mol}$ per liter \\
\hline Ratio of Formic Acid to total Acid & 0.836 & $\mathrm{~mol}$ formic $/ \mathrm{mol}$ acid \\
\hline
\end{tabular}

\subsection{Phase 3 SRAT Product Results}

The elemental compositions for SB5-16 SRAT product matched the sludge recipe targets, as shown in Table 10. Anions and solids are shown in Table 11. 
Table 10 SB5-16 SRAT Product Elements (calcined basis)

\begin{tabular}{||c|c|c||}
\hline & SB5-C & SB5-16 \\
\hline & Recipe & Measured \\
\hline & & Results \\
\hline & Oxide (Wt \%) & Oxide (Wt \%) \\
\hline $\mathrm{Al}_{2} \mathrm{O}_{3}$ & 23.96 & 23.40 \\
\hline $\mathrm{BaO}$ & 0.02 & 0.02 \\
\hline $\mathrm{CaO}$ & 2.77 & 2.73 \\
\hline $\mathrm{Ce}_{2} \mathrm{O}_{3}$ & 0.01 & 0.00 \\
\hline $\mathrm{Cr}_{2} \mathrm{O}_{3}$ & 0.04 & 0.03 \\
\hline $\mathrm{CuO}$ & 0.01 & 0.01 \\
\hline $\mathrm{Fe}_{2} \mathrm{O}_{3}$ & 32.52 & 30.33 \\
\hline $\mathrm{K}_{2} \mathrm{O}$ & 0.06 & 0.17 \\
\hline $\mathrm{La}_{2} \mathrm{O}_{3}$ & 0.01 & 0.00 \\
\hline $\mathrm{MgO}_{2}$ & 1.80 & 1.52 \\
\hline $\mathrm{MnO}_{2}$ & 8.33 & 7.80 \\
\hline $\mathrm{Na}_{2} \mathrm{O}$ & 24.10 & 24.42 \\
\hline $\mathrm{NiO}$ & 3.59 & 3.33 \\
\hline $\mathrm{PbO}_{\mathrm{SiO}}$ & 0.01 & 0.00 \\
\hline $\mathrm{TiO}_{2}$ & 2.72 & 2.80 \\
\hline $\mathrm{U}_{3} \mathrm{O}_{8}$ & 0.02 & 0.00 \\
\hline $\mathrm{ZrO}_{2}$ & 0.01 & 0.00 \\
\hline \hline
\end{tabular}

Table 11 SB5-16 SRAT Product Anion Results

\begin{tabular}{||c|c|c||}
\hline & SB5-16 & Units \\
\hline $\mathrm{F}$ & $<100$ & $\mathrm{mg} / \mathrm{kg}$ slurry \\
\hline $\mathrm{Cl}$ & $<100$ & $\mathrm{mg} / \mathrm{kg}$ slurry \\
\hline $\mathrm{NO}_{2}$ & $<100$ & $\mathrm{mg} / \mathrm{kg}$ slurry \\
\hline $\mathrm{NO}_{3}$ & 29,050 & $\mathrm{mg} / \mathrm{kg}$ slurry \\
\hline $\mathrm{SO}_{4}$ & 130 & $\mathrm{mg} / \mathrm{kg}$ slurry \\
\hline $\mathrm{PO}_{4}$ & $<100$ & $\mathrm{mg} / \mathrm{kg}$ slurry \\
\hline $\mathrm{HCO}_{2}$ & 65950 & $\mathrm{mg} / \mathrm{kg}$ slurry \\
\hline $\mathrm{C}_{2} \mathrm{O}_{4}$ & $<100$ & $\mathrm{mg} / \mathrm{kg}$ slurry \\
\hline Total Solids & 24.62 & $\mathrm{wt} \%$ \\
\hline Soluble Solids & 12.99 & $\mathrm{wt} \%$ \\
\hline Insoluble Solids & 11.64 & $\mathrm{wt} \%$ \\
\hline Calcine Solids & 14.60 & $\mathrm{wt} \%$ \\
\hline pH & 4.20 & $\mathrm{~g} / \mathrm{ml}$ \\
\hline Density & 1.18 & \\
\hline \multicolumn{2}{|l}{} \\
\hline \multicolumn{2}{|c|}{}
\end{tabular}

The results indicate the feed preparation process produced feed that matched the desired elemental composition. Nitrite destruction was completed to below detection limit. Formate 
destruction was $13.5 \%$ compared to a prediction of $15 \%$. Nitrite to nitrate conversion was lower than predicted (18.3\% vs. $25 \%)$. The prediction can be adjusted accordingly for future melt rate feed preparation runs with no mercury or noble metals. 
SRNS-STI-2008-00092

Revision 0

This page intentionally left blank. 


\subsection{MRF TESTING}

The Melt Rate Furnace installed at the ACTL is utilized to compare the melting behavior of different feed formulations for the DWPF. The furnace inner chamber is a cylindrical chamber, approximately $14.2 \mathrm{~L}$ $\left(0.5 \mathrm{ft}^{3}\right)$ in size, with heating coils winding around the chamber walls. The diameter of the chamber is $\sim 17.8 \mathrm{~cm}$ (7 in). Samples are prepared by mixing SRAT product with frit in the proper ratio to obtain the desired waste loading. The material is dried and then screened through a 10 mesh $(1.7 \mathrm{~mm})$ screen before being poured into a $1200-\mathrm{ml}$ stainless steel beaker. The beaker is placed in an insulating sleeve and covered with a vented insulating cover. The furnace is heated to approximately $1150^{\circ} \mathrm{C}$ with the top opening covered. Once the furnace reaches the set point, the cover is removed and the beaker containing sufficient product to produce $525 \mathrm{~g}$ of glass is inserted. When inserted, the beaker bottom is approximately flush with the top of the uppermost chamber coil. After 50 minutes, the beaker is removed from the furnace. There is a twenty minute period between successive tests for the furnace to return to a stable temperature. A beaker containing a Frit 418 standard is fired along with each series of test beakers. After cooling, the beaker is sectioned and the linear melt rate determined by measuring the height of glass formed along the bottom of the beaker.

\subsection{Initial MRF Testing}

The first phase involved MRF testing with 5 frits that covered a range of $\mathrm{B}_{2} \mathrm{O}_{3}$ and alkali concentrations. Frits 418 and 510 were included in the series since they have a well documented history of use in the DWPF and can be used as a baseline for comparison. The SRAT product used for this series of tests was SB5-6 (see Table 5 for compositional information). The results of this MRF testing were initially reported in SRNL-PSE-2008-00098. Data indicates higher total alkali improves melt rate when $\mathrm{B}_{2} \mathrm{O}_{3}$ levels are either $8 \%$ or $14 \%$. A maximum $\mathrm{B}_{2} \mathrm{O}_{3}$ level before melt rate drops off is indicated, but may be confounded by the changing total alkali content. Separate MRF testing for the aluminum dissolution process indicated a critical $\mathrm{B}_{2} \mathrm{O}_{3}+\mathrm{Na}_{2} \mathrm{O}$ content which if exceeded, melt rate was reduced ${ }^{5}$. Table 12 shows both the frit compositions and their respective melt rates. All samples were prepared to target $38 \%$ waste loading.

Table 12 Initial MRF Test Results

\begin{tabular}{||c|c|c|c|c|c|c||}
\hline \hline Frit & $\begin{array}{c}\mathbf{B}_{2} \mathbf{O}_{3} \\
(\mathbf{w t} \%)\end{array}$ & $\begin{array}{c}\mathbf{C a O} \\
(\mathbf{w t} \%)\end{array}$ & $\begin{array}{c}\mathbf{L i}_{2} \mathbf{O} \\
(\mathbf{w t} \%)\end{array}$ & $\begin{array}{c}\mathbf{N a}_{2} \mathbf{O} \\
(\mathbf{w t} \%)\end{array}$ & $\begin{array}{c}\mathbf{S i O}_{2} \\
(\mathbf{w t} \%)\end{array}$ & $\begin{array}{c}\text { Melt Rate } \\
(\mathbf{i n} / \mathbf{h r})\end{array}$ \\
\hline 418 & 8 & - & 8 & 8 & 76 & 0.51 \\
\hline 510 & 14 & - & 8 & 8 & 70 & 0.56 \\
\hline 532 & 14 & 2 & 6 & 7 & 71 & 0.48 \\
\hline 533 & 16 & - & 5 & 8 & 71 & 0.40 \\
\hline 534 & 15 & - & 9 & 4 & 72 & 0.40 \\
\hline Frit Std & - & - & - & - & - & 1.52 \\
\hline
\end{tabular}

Frit 418 and 510 exhibited the highest melt rate in the first series of tests. During this time period, the Tank Farm washing strategy changed which resulted in higher $\mathrm{Na}_{2} \mathrm{O}$ contents in the SB5 projections. With these new projections, Frit 510 was no longer feasible from a Measurement Acceptability Region (MAR) paper study assessment perspective. Although Frit 
510 was used in the Phase 1 MRF testing; Frit 503, along with Frit 418, were selected to support Phase 2 testing (i.e. assessment of the impact of waste loading on melt rate). Frit 503 has the same $\mathrm{B}_{2} \mathrm{O}_{3}$ and $\mathrm{Li}_{2} \mathrm{O}$ concentrations as Frit 510, but contains 4 wt \% less sodium and subsequently 4 wt $\%$ more $\mathrm{SiO}_{2}$ (to compensate for the $\mathrm{Na}_{2} \mathrm{O}$ increase in the projection). The use of these two frits (Frit 503 and Frit 418) in Phase 2 should allow for a more direct comparison of the compositional impacts of $\mathrm{B}_{2} \mathrm{O}_{3}$ and $\mathrm{Na}_{2} \mathrm{O}$ (at a fixed $\mathrm{Li}_{2} \mathrm{O}$ content) on melt rate for a SB5-like system - minimizing the confounding effects observed with the Phase 1 testing.

\subsection{Phase Two Testing}

The Phase 2 tests involved two waste loading values with limited replication. SB5-6 SRAT product was mixed with Frits 418 and 503 at both 34\% and 38\% waste loading. The results of the MRF tests are shown in Table 13.

Table 13 SB5 Waste Loading Results

\begin{tabular}{||c|c|c|c|c||}
\hline Frit & $\begin{array}{c}\text { Waste } \\
\text { Loading } \\
\text { (\%) }\end{array}$ & $\begin{array}{c}\text { Test \#1 } \\
\text { (in/hr) }\end{array}$ & $\begin{array}{c}\text { Test \#2 } \\
\text { (in/hr) }\end{array}$ & $\begin{array}{c}\text { Avg Melt } \\
\text { Rate } \\
\text { (in/hr) }\end{array}$ \\
\hline 418 & 34 & .47 & .37 & 0.42 \\
\hline 418 & 38 & .41 & $*$ & 0.41 \\
\hline 503 & 34 & .42 & .44 & 0.43 \\
\hline 503 & 38 & .35 & $*$ & 0.35 \\
\hline Frit Std & & & & 1.51 \\
\hline
\end{tabular}

* Not enough SRAT product for replication

Reduced melt rates were observed with increased waste loading for both frits in the first set of samples (Test \#1). This trend is consistent with historical data between melt rate and waste loading. The incomplete set of replicates (i.e. no $38 \% \mathrm{WL}$ data for Test $\# 2$ due to insufficient SRAT product) does not allow for a confirmation of this trend with these specific systems. Figure 1 shows that both frits produced similar melt patterns when the beakers were sectioned. A layer of small bubbles along the top of the glass in the bottom of the beaker reduces the measured melt rate compared to samples that exhibit a more solid appearance. 
Figure 1. Frit 418 (left) and Frit 503 (right) Sectioned Beakers
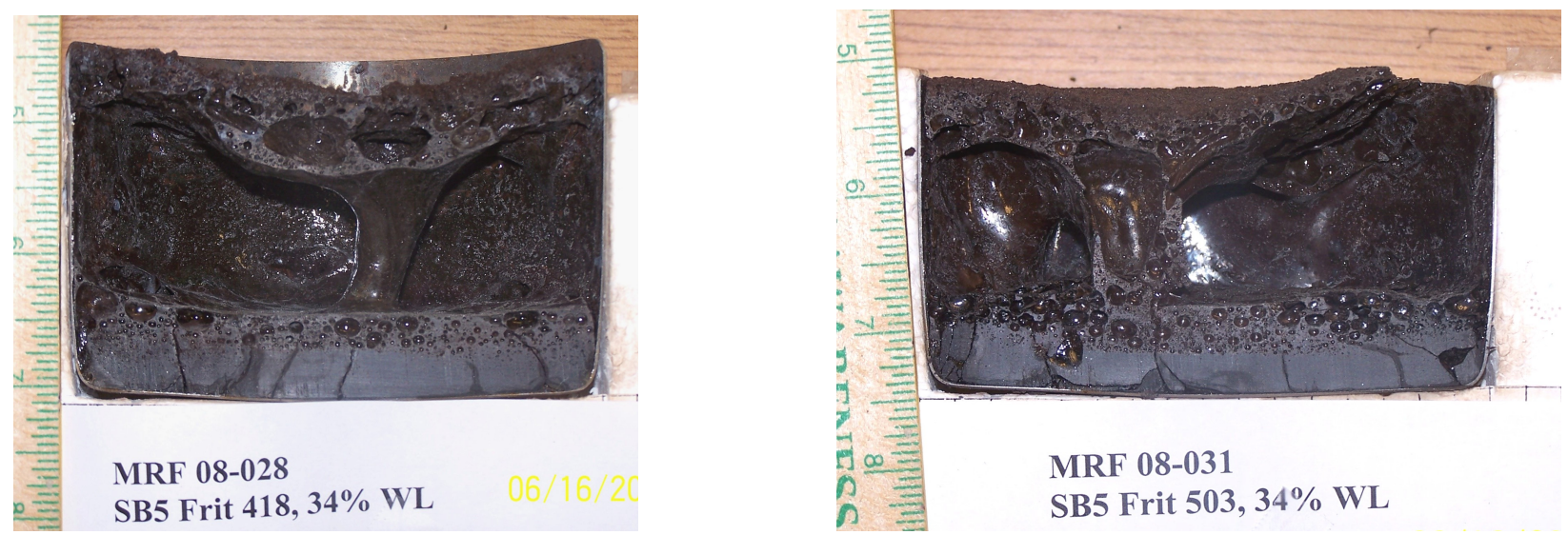

Both the Phase 1 and Phase 2 SB5 MRF tests exhibited an unusual property during the sample preparation: they were harder to break into small pieces for screening than previous sample preparations with SB4. The additional grinding time may have resulted in a different final particle size distribution in the beaker. That is only an observation and may not influence the melt rate results, since they are compared internally and not across batches

\subsection{Phase Three Testing}

The final series of tests included Frit 418 and a series of new frits that had increased $\mathrm{B}_{2} \mathrm{O}_{3}$ values along with varying alkali contents. All samples were batched at $36 \%$ waste loading with the frit compositions shown in Table 14. A replicate of each frit-WL series was included during the Phase 3 testing. SRAT product SB5-16 was used for this test series. Preparation of the SRAT product was covered previously in Section 2.5. Testing was conducted using standard procedures along with a run plan SRNL-PSE-2008-00168.

Table 14 Candidate SB5 Frit Compositions (Weight \%)

\begin{tabular}{||c|c|c|c|c|c||}
\hline Frit & $\mathbf{B}_{\mathbf{2}} \mathbf{O}_{3}$ & $\mathbf{C a O}$ & $\mathbf{L i}_{\mathbf{2}} \mathbf{O}$ & $\mathbf{N a}_{\mathbf{2}} \mathbf{O}$ & $\mathbf{S i O}_{\mathbf{2}}$ \\
\hline 418 & 8 & - & 8 & 8 & 76 \\
\hline 540 & 12 & 2 & 6 & 8 & 72 \\
\hline 541 & 15 & - & 5 & 10 & 70 \\
\hline 542 & 18 & - & 4 & 10 & 68 \\
\hline
\end{tabular}

All of the samples for the third phase of testing were fired on August 7, 2008 along with a Frit 418 standard. Measured melt rate results are shown in Table 15. 
Table 15 Phase Three Melt Rate Results

\begin{tabular}{|c|c|c|c||}
\hline Frit & $\begin{array}{c}\text { Test \#1 } \\
\text { (in/hr) }\end{array}$ & $\begin{array}{c}\text { Test \#2 } \\
\text { (in/hr) }\end{array}$ & $\begin{array}{c}\text { Avg Melt } \\
\text { Rate } \\
\text { (in/hr) }\end{array}$ \\
\hline 540 & 0.61 & 0.65 & 0.63 \\
\hline 418 & 0.55 & 0.59 & 0.57 \\
\hline 541 & 0.51 & 0.56 & 0.54 \\
\hline 542 & 0.45 & 0.41 & 0.43 \\
\hline Frit Std & 1.58 & - & 1.58 \\
\hline
\end{tabular}

Frit 540 and Frit 418 demonstrated the highest melt rates, followed by Frit 541 and then Frit 542 . The replicated samples showed similar values when measured. The trend of higher melt rate with increased alkali (below a $\mathrm{B}_{2} \mathrm{O}_{3}$ threshold) is repeated in this series. Visual observation clearly showed that Frit 542 did not produce a consistent layer of glass in the bottom of the beaker, which is reflected in the reduced melt rate. A comparison of the melting behavior of Frit 540 and Frit 542 is shown in Figure 2.

Figure 2 Frit 540 (left) and Frit 542 (right) Sectioned Beakers
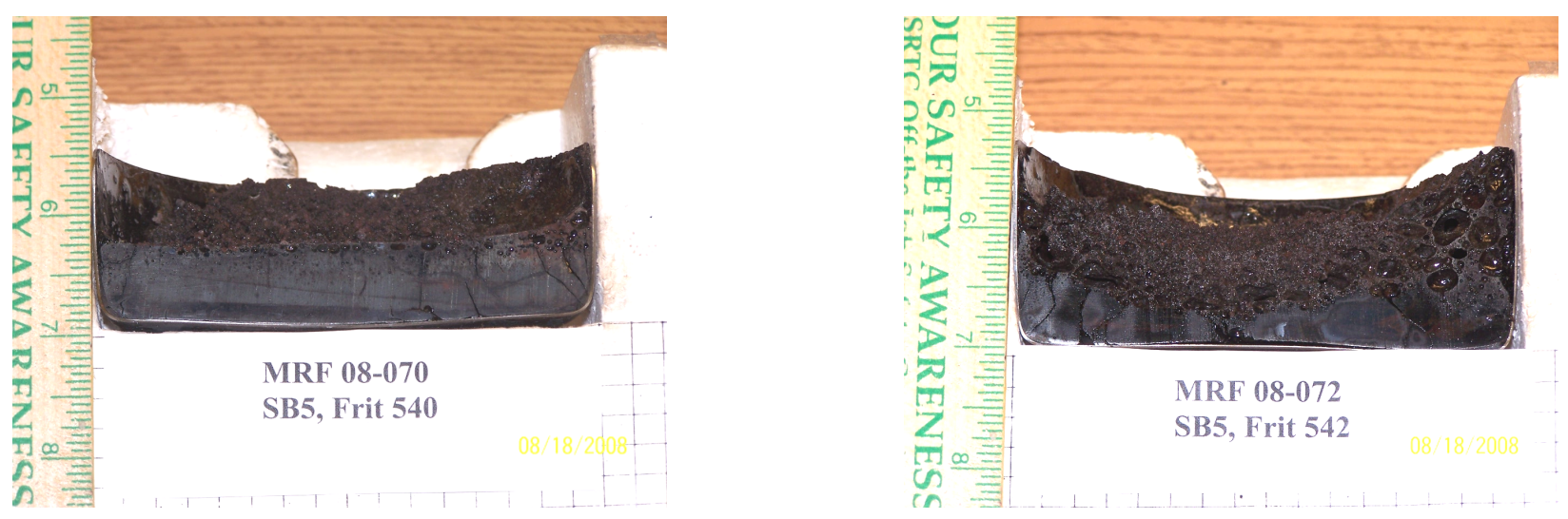

Material from this phase of the testing was not as difficult to screen as the dried material from the first two phases. Some samples were easier than others to break and screen, but overall the entire series processed more readily.

One aspect not specifically addressed in this testing was reduction/oxidation (REDOX) of the feed. The DWPF controls the melt REDOX between $0.09 \leq \mathrm{Fe}^{2+} / \Sigma \mathrm{Fe} \leq 0.33$. Recent testing ${ }^{5}$ in the sludge mass reduction program indicated that totally oxidized feed could skew the test results. As part of a REDOX validation study ${ }^{6}$, multiple samples were tested. One sample designated as SB5-12-2554, was tested in triplicate and the results indicated a REDOX value of 0.26. This sludge material was the same used to prepare the SRAT product (SB-16) for the MRF phase 3 testing. This indicated that REDOX should not have played a major role in the results of this test series. Based on the similar acid calculation basis used in both SRAT batches, it is a fair assumption that REDOX also did not play a major role in the phase 1 or phase 2 MRF test results. 
SRNS-STI-2008-00092

Revision 0

This page intentionally left blank. 


\subsection{CONCLUSIONS/RECOMMENDATIONS}

Several general conclusions can be derived from MRF testing with SB5.

- $\quad$ Frit 418 is robust to compositional variation in the sludge, continues to be a possible candidate for SB5 vitrification and has a history of performance in DWPF.

- $\quad$ Based solely on MRF results, which do not evaluate rheological properties, candidate frits are available that will not severely impact melt rates, compared to the SB4/Frit 510 system. For example: melt rates of $0.63 \mathrm{in} / \mathrm{hr}$ for Frit 540/SB5 (@36\% waste loading) vs. rates of 0.66 in/hr for Frit 510/SB4 (@38\% waste loading) from previous studies.7

- $\quad$ There appear to be maximum values for $\mathrm{B}_{2} \mathrm{O}_{3}(\sim 14 \mathrm{wt} \%)$ and $\mathrm{Na}_{2} \mathrm{O}(\sim 9$ wt \%) concentrations in frit after which melt rate is either constant or begins to decrease.

Trends observed in this testing followed patterns similar to earlier studies ${ }^{7}$ with Sludge Batch 3 (SB3) and Sludge Batch 5 (SB4), in which melt rate was sensitive to increases in boron and sodium concentrations. Recent testing ${ }^{5}$ to evaluate the effect of aluminum dissolution on melt rate also show a similar relationship between boron and alkali ratios.

Results of the melt rate testing for SB5 led to the selection of two frits for further testing: Frit 418 and Frit 540. A review of the projected operating windows using the PCCS models and the MAR acceptability criteria indicates that a minor modification to Frit 540 would yield a slightly larger operating window, especially with regard to viscosity constraints. Frit 550 contains the same $\mathrm{B}_{2} \mathrm{O}_{3}$ content as Frit 540 , but the $\mathrm{CaO}$ is replaced with $\mathrm{Li}_{2} \mathrm{O}$. In order to widen the projected operating window even further, the $\mathrm{Na}_{2} \mathrm{O}$ concentration was reduced by $1 \mathrm{wt} \%$, which was compensated by an increase in the $\mathrm{SiO}_{2}$ concentration to $73 \mathrm{wt} \%$. Frit 550 will be used in place of Frit 540 for additional testing with melt rate anticipated to be similar to Frit 540.

All of the results evaluated have been fired in the Melt Rate Furnace. This is a dry fed system that does not give an indication of potential problems associated with slurry feeding (which may be associated with SB5 due to rheological changes based on the Al-dissolution flowsheet). In order to gain insight into the feeding behavior of the SB5 system, two Slurry-Fed Melt Rate Furnace runs will be completed using Frit 418 and Frit 550, once Frit 550 has been obtained. Assessment of the potential impacts of rheology on melt rate will depend on the ability of the simulated SRAT produced to support SMRF testing to match that of the radioactive SB5 sample. Frit 418 will be used initially for SB5 processing in DWPF ${ }^{8}$. Recommendation for implementation of Frit 550 will be based on data from SMRF testing. 
SRNS-STI-2008-00092

Revision 0

This page intentionally left blank. 


\subsection{REFERENCES}

1. Culbertson, B. H., Sludge Batch 5 Frit Optimization, HLW-DWPF-TTR-2007-0007, Washington Savannah River Company, Aiken, South Carolina.

2. Peeler, D. P., Sludge Batch 5 Frit Optimization, WSRC-STI-2006-00321, Washington Savannah River Company, Aiken, South Carolina.

3. Fox, K. M., and T. B. Edwards, SB5 with the Estimated Impact of Low-Temperature Aluminum Dissolution: Preliminary Frits for Melt Rate Testing, WSRC-STI-2008-00006, Washington Savannah River Company, Aiken, South Carolina.

4. Lambert, D. P., M .E. Stone, B. R. Pickenheim, D. R. Best, and D. C. Koopman, Sludge Batch 5 Simulant Flowsheet Studies, SRNS-STI-2008-00024, Rev B, Savannah River National Laboratory, Aiken, South Carolina.

5. Newell, J. D., and D. H. Miller, Factors That Influence Melt Rate for Future Sludge Batch Projections, SRNS-STI-2008-00081, Savannah River National Laboratory, Aiken South Carolina.

6. Jantzen, C. M., and J. D. Newell, Defense Waste Processing Facility (DWPF) Sludge Batch 5 (SB5) REDOX Validation, SRNL-PSE-2008-00184, Savannah River National Laboratory, Aiken, South Carolina.

7. Smith, M. E., T. M. Jones, and D. H. Miller, Sludge Batch 4 Baseline Melt Rate Furnace and Slurry-Fed Melt Rate Furnace Tests with Frits 418 and 510, WSRC-STI-2007-00450, Washington Savannah River Company, Aiken, South Carolina.

8. Fox, K. M., T. B. Edwards, and D. K. Peeler, Recommended Frit Composition for Initial Sludge Batch 5 Processing at the Defense Waste processing Facility, WSRC-STI-2008-00338, Savannah River National Laboratory, Aiken, South Carolina. 
SRNS-STI-2008-00092

Revision 0

APPENDIX 


\section{Appendix A. Acid Equation Inputs and Results for SB5-6}

\begin{tabular}{|c|c|c|}
\hline Sludge Analyses for Acid Calculations & SB5-6 & \\
\hline Fresh Sludge Mass without trim chemicals & $17,330.0$ & g slurry \\
\hline Fresh Sludge Weight \% Total Solids & 17.48 & $\mathrm{wt} \%$ \\
\hline Fresh Sludge Weight \% Calcined Solids & 13.52 & $\mathrm{wt} \%$ \\
\hline Fresh Sludge Weight \% Insoluble Solids & 11.13 & wt $\%$ \\
\hline Fresh Sludge Density & 1.170 & $\mathrm{~kg} / \mathrm{L}$ slurry \\
\hline Fresh Sludge Nitrite & 7,545 & $\mathrm{mg} / \mathrm{kg}$ slurry \\
\hline Fresh Sludge Nitrate & 5,610 & $\mathrm{mg} / \mathrm{kg}$ slurry \\
\hline Fresh Sludge Oxalate & 0 & $\mathrm{mg} / \mathrm{kg}$ slurry \\
\hline Fresh Sludge Formate & 0 & $\mathrm{mg} / \mathrm{kg}$ slurry \\
\hline Fresh Sludge Coal/Carbon source & 0.000 & wt $\%$ dry basis \\
\hline Fresh Sludge Manganese ( $\%$ of Calcined Solids) & 4.325 & wt $\%$ calcined basis \\
\hline Fresh Sludge Slurry TIC (treated as Carbonate) & 1,480 & $\mathrm{mg} / \mathrm{kg}$ slurry \\
\hline Fresh Sludge Hydroxide (Base Equivalents) $\mathrm{pH}=7$ & 1.015 & Equiv Moles Base/L slurry \\
\hline Fresh Sludge Mercury ( $\%$ of Total Solids in untrimmed sludge) & 0.0000 & wt $\%$ dry basis \\
\hline Fresh Sludge Supernate manganese & 0 & $\mathrm{mg} / \mathrm{L}$ supernate \\
\hline Fresh Sludge Supernate density & 1.04 & $\mathrm{~kg} / \mathrm{L}$ supernate \\
\hline SRAT Processing Assumptions & SB5-6 & \\
\hline Conversion of Nitrite to Nitrate in SRAT Cycle & 25.00 & $\mathrm{gmol} \mathrm{NO}_{3}{ }^{-} / 100 \mathrm{gmol} \mathrm{NO}_{2}^{-}$ \\
\hline Destruction of Nitrite in SRAT and SME cycle & 100.00 & $\%$ of starting nitrite destroyed \\
\hline Destruction of Formic acid charged in SRAT & 10.00 & $\%$ formate converted to $\mathrm{CO}_{2}$ etc. \\
\hline Destruction of oxalate charged & 50.00 & $\%$ of total oxalate destroyed \\
\hline Percent Acid in Excess Stoichiometric Ratio & 130.00 & $\%$ \\
\hline SRAT Product Target Solids & 25.00 & $\%$ \\
\hline Nitric Acid Molarity & 10.534 & Molar \\
\hline Formic Acid Molarity & 23.600 & Molar \\
\hline DWPF Nitric Acid addition Rate & 2.0 & gallons per minute \\
\hline DWPF Formic Acid addition Rate & 2.0 & gallons per minute \\
\hline REDOX Target & 0.200 & $\mathrm{Fe}^{+2} / \Sigma \mathrm{Fe}$ \\
\hline REDOX Equation ( 7 for $\mathrm{Mn}^{+7}$, otherwise assumes $\mathrm{Mn}^{+4}$ ) & 年 & Enter 7 for new redox equation \\
\hline Trimmed Sludge Target Ag metal content & 0.00000 & total wt $\%$ dry basis after trim \\
\hline Trimmed Sludge Target wt $\% \mathrm{Hg}$ dry basis & 0.00000 & total $\mathrm{wt} \%$ dry basis after trim \\
\hline Trimmed Sludge Target Pd metal content & 0.00000 & total $\mathrm{wt} \%$ dry basis after trim \\
\hline Trimmed Sludge Target Rh metal content & 0.00000 & total $w t \%$ dry basis after trim \\
\hline Trimmed Sludge Target Ru metal content & 0.00000 & total $\mathrm{wt} \%$ dry basis after trim \\
\hline Trimmed Sludge Target Wt\% Coal/carbon source dry basis & 0.00 & total $\mathrm{wt} \%$ dry basis after trim \\
\hline Trimmed Sludge Target oxalate after trim (wt \% not mg/kg) & 0.000 & total $\mathrm{wt} \%$ dry basis after trim \\
\hline Water to dilute fresh sludge and/or rinse trim chemicals & 500.000 & $\mathrm{~g}$ \\
\hline Total Water added to flush the Nitric and Formic Acid Lines & 50.0 & g \\
\hline Sample Mass of Trimmed sludge (SRAT Receipt sample, if any) & 0.0 & $\mathrm{~g}$ \\
\hline Mass of SRAT cycle samples & 0.000 & g \\
\hline Wt\% Active Agent In Antifoam Solution & 10 & $\%$ \\
\hline $\begin{array}{l}\text { Basis Antifoam Addition for SRAT (generally } 100 \mathrm{mg} \\
\text { antifoam/kg slurry) }\end{array}$ & 100.00 & $\mathrm{mg} / \mathrm{kg}$ slurry \\
\hline Number of basis antifoam additions added during SRAT cycle & 7.00 & \\
\hline \multicolumn{3}{|l|}{ Results of Acid Calculation } \\
\hline & SB5-6 & \\
\hline Acid Addition Amount & 2.076 & g/mol per liter \\
\hline Ratio of Formic Acid to total Acid & 0.818 & mol formic/mol acid \\
\hline
\end{tabular}




\section{Appendix B. Acid Equation Inputs and Results for SB5-16}

\begin{tabular}{|c|c|c|}
\hline \multicolumn{3}{|l|}{ Sludge Analyses for Acid Calculations } \\
\hline \multicolumn{3}{|l|}{ Fresh Sludge Mass without trim chemicals } \\
\hline Fresh Sludge Weight \% Total Solids & 12.50 & $\mathrm{wt} \%$ \\
\hline Fresh Sludge Weight \% Calcined Solids & 9.51 & $w t \%$ \\
\hline Y Fresh Sludge Weight \% Insoluble Solids & 7.85 & $\mathrm{wt} \%$ \\
\hline Fresh Sludge Density & 1.090 & kg / L slurry \\
\hline Fresh Sludge Nitrite & 6,175 & $\mathrm{mg} / \mathrm{kg}$ slurry \\
\hline Fresh Sludge Nitrate & 3,940 & $\mathrm{mg} / \mathrm{kg}$ slurry \\
\hline Fresh Sludge Oxalate & 0 & $\mathrm{mg} / \mathrm{kg}$ slurry \\
\hline Fresh Sludge Formate & 0 & $\mathrm{mg} / \mathrm{kg}$ slurry \\
\hline Fresh Sludge Coal/Carbon source & 0.000 & wt $\%$ dry basis \\
\hline Fresh Sludge Manganese (\% of Calcined Solids) & 5.050 & wt $\%$ calcined basis \\
\hline Fresh Sludge Slurry TIC (treated as Carbonate) & 1,338 & $\mathrm{mg} / \mathrm{kg}$ slurry \\
\hline Fresh Sludge Hydroxide (Base Equivalents) $\mathrm{pH}=7$ & 0.632 & Equiv Moles Base/L slurry \\
\hline Fresh Sludge Mercury ( $\%$ of Total Solids in untrimmed sludge) & 0.0000 & wt $\%$ dry basis \\
\hline Fresh Sludge Supernate manganese & 0 & $\mathrm{mg} / \mathrm{L}$ supernate \\
\hline Fresh Sludge Supernate density & 1.024 & $\mathrm{~kg} / \mathrm{L}$ supernate \\
\hline Table 2 -- SRAT Processing Assumptions, Run \# & SB5-16 & \\
\hline \multirow{2}{*}{$\begin{array}{l}\text { Conversion of Nitrite to Nitrate in SRAT Cycle } \\
\text { Destruction of Nitrite in SRAT and SME cycle }\end{array}$} & 25.00 & $\mathrm{gmol} \mathrm{NO}_{3}^{-} / 100 \mathrm{gmol} \mathrm{NO}_{2}^{-}$ \\
\hline & 100.00 & $\%$ of starting nitrite destroyed \\
\hline \multirow{2}{*}{$\begin{array}{l}\text { Destruction of Formic acid charged in SRAT } \\
\text { Destruction of oxalate charged }\end{array}$} & 15.00 & $\%$ formate converted to $\mathrm{CO}_{2}$ etc. \\
\hline & 50.00 & $\%$ of total oxalate destroyed \\
\hline Percent Acid in Excess Stoichiometric Ratio & 130.00 & $\%$ \\
\hline SRAT Product Target Solids & 25.00 & $\%$ \\
\hline Nitric Acid Molarity & 10.534 & Molar \\
\hline Formic Acid Molarity & 23.600 & Molar \\
\hline DWPF Nitric Acid addition Rate & 2.0 & gallons per minute \\
\hline DWPF Formic Acid addition Rate & 2.0 & gallons per minute \\
\hline REDOX Target & 0.200 & $\mathrm{Fe}^{+2} / \Sigma \mathrm{Fe}$ \\
\hline REDOX Equation ( 7 for $\mathrm{Mn}^{+7}$, otherwise assumes $\mathrm{Mn}^{+4}$ ) & 7 & Enter 7 for newest redox equation \\
\hline Trimmed Sludge Target Ag metal content & 0.00000 & total wt $\%$ dry basis after trim \\
\hline Trimmed Sludge Target wt $\% \mathrm{Hg}$ dry basis & 0.00000 & total $\mathrm{wt} \%$ dry basis after trim \\
\hline Trimmed Sludge Target Pd metal content & 0.00000 & total $\mathrm{wt} \%$ dry basis after trim \\
\hline Trimmed Sludge Target $\mathrm{Rh}$ metal content & 0.00000 & total $\mathrm{wt} \%$ dry basis after trim \\
\hline Trimmed Sludge Target Ru metal content & 0.00000 & total $\mathrm{wt} \%$ dry basis after trim \\
\hline Trimmed Sludge Target $\mathrm{Wt} \%$ Coal/carbon source dry basis & 0.00 & total $\mathrm{wt} \%$ dry basis after trim \\
\hline Trimmed Sludge Target oxalate after trim (wt \% not mg/kg) & 0.000 & total $\mathrm{wt} \%$ dry basis after trim \\
\hline Water to dilute fresh sludge and/or rinse trim chemicals & 0.000 & g \\
\hline Total Water added to flush both the Nitric and Formic Acid Lines & 50.0 & g \\
\hline Sample Mass of Trimmed sludge (SRAT Receipt sample, if any) & 0.0 & $\mathrm{~g}$ \\
\hline Mass of SRAT cycle samples & 0.000 & $\mathrm{~g}$ \\
\hline Wt $\%$ Active Agent In Antifoam Solution & 10 & $\%$ \\
\hline $\begin{array}{l}\text { Basis Antifoam Addition for SRAT (generally } 100 \mathrm{mg} \\
\text { antifoam/kg slurry) }\end{array}$ & 100.00 & $\mathrm{mg} / \mathrm{kg}$ slurry \\
\hline Number of basis antifoam additions added during SRAT cycle & 7.00 & \\
\hline
\end{tabular}




\section{Distribution:}

J.C. Griffin, 773-A

A. B. Barnes, 999-W

D. A. Crowley, 773-43A

S. D. Fink, 773-A

C. W. Gardner, 773-A

B. J. Giddings, 786-5A

C. C. Herman, 999-W

D. J. McCabe, 773-42A

J. E. Occhipinti, 704-S

D. C. Sherburne, 704-S

R. T. McNew, 704-27S

J. F. Iaukea, 704-30S

J. W. Ray, 704-S

E. W. Holtzscheiter, 704-15S

M. E. Smith, 704-30S

H. B. Shah, 766-H

J. M. Gillam, 766-H

B. A. Hamm, 766-H

D. D. Larsen, 766-H

C. J. Bannochie, 773-42A

D. K. Peeler, 999-W

M. E. Stone, 999-W

B. A. Davis, 704-27S

J. M. Bricker, 704-27S

T. L. Fellinger, 704-26S

M. T. Keefer, 766-H 